\begin{tabular}{|c|}
\hline $\mathbf{R}_{\text {ESEARCH }} \mathbf{P}_{\text {APER }}$ \\
\hline
\end{tabular}

\title{
Sensory evaluation and chemical composition of shrikhand blended with unripe banana
}

\author{
D.R. Bhoyar, P. A. Kahate, R.R. Shelke and H.V. WadatKar
}

\begin{abstract}
The present investigation entitled "Sensory evaluation and chemical composition of shrikhand blended with unripe banana" was undertaken in the Department of Animal Husbandry and Dairy Science Dr. Panjabrao Deshmukh Krishi Vidyapeeth, Akola during the year 2013-2014. The efforts were made to incorporate the nutritional value of banana in shrikhand and prepared the value added fermented dairy product. The investigation was planned with main objectives to standardize the optimum level of unripe banana pulp in shrikhand, sensory evaluation and determination of chemical composition of shrikhand. It was found that blending of 20 per cent unripe banana in cow milk chakka produce a good and more acceptable quality shrikhand. Regarding chemical composition it was found that, fat, protein, total solids and titratable acidity was decreased with increase in rate of addition of unripe banana while, solids not fat and moisture content was increased with increased in the level of addition of unripe banana pulp in shrikhand.
\end{abstract}

Key Words : Shrikhand, Unripe banana pulp, Sensory evaluation, Chemical composition

How to cite this article : Bhoyar, D.R., Kahate, P.A., Shelke, R.R. and Wadatkar, H.V. (2015). Sensory evaluation and chemical composition of shrikhand blended with unripe banana. Food Sci. Res. J., 6(1): 40-44. 